\title{
Factors Influencing Capital Expenditure Achievement in West Sumatra
}

\author{
Efrizal Syofyan', Selfin Kristianti Waruwu', Sany Dwita ${ }^{3}$ \\ ${ }^{1}$ Faculty of Economics, Universitas Negeri Padang, Padang, Indonesia, \\ $\triangle$ (e-mail) efrizal_syofyan@yahoo.com \\ ${ }^{2}$ Faculty of Economics, Universitas Negeri Padang, Padang, Indonesia, \\ $\square$ (e-mail) selfinkristianti@yahoo.com \\ ${ }^{3}$ Faculty of Economics, Universitas Negeri Padang, Padang, Indonesia, \\ $\square$ (e-mail) sany@fe.unp.ac.id
}

\begin{abstract}
The purpose of this study is to examine the influence of leadership, applicable regulations and human resources competence on the capital expenditure achievement level at West Sumatera local government. Based on the literature, this study formulates three hypotheses in regards to leadership, applicable regulations and human resources competence. The data for this study were collected by using a survey questionnaire administered to 48 Organization of Regional Devices (Organisasi Perangkat Daerah-OPD) in West Sumatera. The data were analyzed using multiple regression analysis. The results of this study show that leadership has a significant influence on budget achievement level, the applicable regulations have a significant influence on budget achievement level, that human resources competence have a significant influence on budget achievement level.
\end{abstract}

Keywords: capital expenditure achievement, leadership, applicable regulations, and human resources competence

\section{Introduction}

Along with the development of the reform era, there are demands to improve the performance of public sector organizations to be more oriented towards the realization of services for people who need goods or public services. In the public sector, a budget is a political document as a form of commitment between the legislative and the executive over the use of public funds for a particular interest. Public sector budget is an activity plan presented in the form of revenue and expenditure in monetary units (Mardiasmo, 2009). Budget as the blue print of the existence of a state is created to help improve the services of interests and public needs, improve the welfare of the community, implement development and facilities reflected in capital expenditures.

Performance-based budgeting (PBB) system is a mechanism aimed at improving the efficiency of allocation and productivity of public sector financing by strengthening the relationship between available budgets with outcomes or outputs through the use of information or performance measurement in resource allocation decision making (Bastian, 2010). The problem in this study is the implementation of the budget that is not necessarily successful. Indeed, the level of budget achievement is not optimal because of budget indiscipline, limited budget time where the work has not yet finished by the end of the budget year. Moreover, inadequate capability and competency and the lack of sound leadership in the executive part, as well as administration and accountability weaknesses in relation rules and regulations may influence the level of capital expenditure achievement (Fitri, Ludigdo, \& Djamhuri, 2013).

According to Bastian (2010), public budgets can be interpreted as a package of statements concerning expected revenues and expenditures that are expected to occur in one or more future periods. Performance-based budgeting is a method of budgeting for management to link any funding outlined in activities with expected outputs and outputs, including efficiency in achieving the outcomes of those outputs (Kurniawan, 2009).

According to George (as cited in Gouzali, 2005), leadership is the whole activity or activity to influence the willingness of others to achieve goals. In another sense, leadership is more of a person's 
ability (whether in the organization or not) to influence the people in their environment, so that they are willing to work towards the goal the leader wants. In relation to prevailing regulations, the management of state finance is based on the budget implementation module issued by the Ministry of Finance of the Republic of Indonesia. The module states that with the enactment of the provisions of the Law on State Finance, namely, Law No. 17/2003, Law Number 1 of 2004, and Law No. 15 of 2004.

According to Ruky (2014), competence is the basic (and hidden) characteristics of a person who has a causal relationship with superior or excellent performance on the basis of predetermined criteria in a particular job or situation. Human Resource Development (HRD) is an activity that must be implemented by the organization or company. By so doing, there will be the existence of knowledge, skills and skilled employees in accordance with the demands of work (Gouzali, 2005).

The hypotheses formulated for thus study are as follows.

$\mathrm{H}_{1}$ : Leadership has significant effect on capital expenditure achievement.

$\mathrm{H}_{2}$ : Prevailing regulations have significant influence on the level of capital expenditure achievement.

$\mathrm{H}_{3}$ : Human resources competence has significant influence on the level of capital expenditure achievement.

The remainder of this paper is organized as follows. The next section presents the research methods and then followed by results and discussion. The final section concludes the paper and discussed the limitations.

\section{Methods}

As indicated by the previous section, this study is a causative research. The population in this study is 48 Organization of Regional Devices (OPD) in Province West Sumatera. Total sampling technique was used, so that all members of the population were chosen to be the study. The type of data used in this study is subject data (self-reported data) in the form of opinions and perceptions, attitudes, experiences or characteristics of a person or a group of people who become the subject of research (respondents). Data source in this research is primary data, that is data obtained directly from data source.

The data in this study were collected by administering questionnaires to respondents. In this research, questionnaire distribution was conducted to find out data related to the influence of leadership, applicable regulation and human resource competency on the level of capital expenditure achievement in West Sumatera. Then, as additional information, an interview was conducted with respondent. The multiple regression analysis was used to analyzed the data collected to test the hypotheses.

\section{Results and Discussion}

A preliminary analysis was conducted to test the data validity using the corrected item total correlation value for leadership $\left(X_{1}\right)$, applicable regulations $\left(X_{2}\right)$, human resource competence $\left(X_{3}\right)$ and level of budget achievement $(Y)$. Based on the values, it can be concluded that all variables are valid. The results of reliability testing of leadership, applicable regulations, human resource competencies and budget performance level show that Cronbach alpha values are in the range above 0.60 (0.913; $0.810 ; 0.832 ; 0.764$, respectively).

The results of normality test in this study can be seen in the Table 1 . Table 1 shows that the Kolmogorov-Smirnov values for level of budget achievement, leadership, the applicable rules, and of human resources competence are $0.071,0.072$, of 0.2 , and 0.054 , respectively. All variables in this study have Kolmogorov-Smirnov values higher than the significant level of 0.05 . So, it can be concluded that the data used in this study are normally distributed. 
Table 1 One-Sample Kolmogorov-Smirnov Test

\begin{tabular}{lccccc}
\hline & & $\mathrm{Y}$ & $\mathrm{X}_{1}$ & $\mathrm{X}_{2}$ & $\mathrm{X}_{3}$ \\
\hline \multicolumn{1}{c}{$\mathrm{N}$} & & 70 & 70 & 70 & 70 \\
\hline $\begin{array}{l}\text { Normal } \\
\text { Parameters }\end{array}$ & Mean & 37.91 & 35.56 & 48.46 & 30.30 \\
\cline { 2 - 6 } & $\begin{array}{c}\text { Std. } \\
\text { Deviation }\end{array}$ & 9.544 & 8.091 & 4.889 & 2.628 \\
\hline $\begin{array}{l}\text { Most } \\
\text { Extreme }\end{array}$ & Absolute & 0.102 & 0.101 & 0.080 & 0.105 \\
\cline { 2 - 6 } \begin{tabular}{l} 
Differences \\
\cline { 2 - 6 }
\end{tabular} & Positive & 0.068 & 0.095 & 0.080 & 0.095 \\
\hline $\begin{array}{l}\text { Kolmogorive } \\
\text { Smirnov Z }\end{array}$ & -0.102 & -0.101 & -0.051 & -0.105 \\
\hline $\begin{array}{l}\text { Asymp. Sig. } \\
\text { (2-tailed) }\end{array}$ & 0.102 & 0.101 & 0.080 & 0.105 \\
\hline
\end{tabular}

The multicollinearity test in this study is conducted by testing the variance inflation factor (VIF) and tolerance values for each of independent variables. The results of the multicollinearity test show that the VIF value for each of independent variables in the regression model is not correlated. The VIF value for leadership is 1.071 and tolerance value is 0.934 . For the applicable regulations, the VIF value is 1.058 and the tolerance value of 0.946 . While, for human resource competence obtained, the VIF value is 1.013 and tolerance value of 0.987 . Overall, all independent variables in this study have VIF value less than 10 and tolerance value higher than 0.10 . It shows that there is no correlation between the independent variables in the regression model and it is concluded that there is no multicollinearity problems among the independent variables in the regression model.

Heteroscedasticity test in this study was conducted by using Glejser test. The results of heteroscedasticity test are presented in Table 2 .

Table 2 Results of Glesjer Test

\begin{tabular}{cccccc}
\hline \multirow{2}{*}{ Model } & \multicolumn{2}{c}{$\begin{array}{c}\text { Unstandardized } \\
\text { Coefficients }\end{array}$} & $\begin{array}{c}\text { Standardized } \\
\text { Coefficients }\end{array}$ & \multirow{2}{*}{ s } & sig. \\
\cline { 2 - 6 } & $\mathrm{B}$ & Std. Error & Beta & & \\
\hline 1 (constant) & 17.333 & 8.081 & & 2.145 & 0.036 \\
\hline X1 & -0.076 & 0.063 & -0.149 & -1.200 & 0.234 \\
\hline X2 & -0.014 & 0.104 & -0.017 & -0.135 & 0.893 \\
\hline X3 & -0.216 & 0.189 & -0.138 & -1.142 & 0.258 \\
\hline
\end{tabular}

Based on results in Table 2, it can be seen that the calculation results for each of independent variables has a significant value that is higher than the significance level of 0.05 . Each independent variable of leadership, applicable regulations and human resource competence has a significant value $0.234,0.893,0.258$, respectively. So, it can be concluded that the model is not exposed to symptoms of heteroscedasticity.

The hypotheses testing in this study was conducted by using multiple regression analysis. The results of hypotheses tests are presented in Table 3.

Table 3 Results of regression analysis

\begin{tabular}{cccccc}
\hline \multirow{2}{*}{ Model } & \multicolumn{2}{c}{$\begin{array}{l}\text { Unstandardized } \\
\text { Coefficients }\end{array}$} & $\begin{array}{c}\text { Standardized } \\
\text { Coefficients }\end{array}$ & $t$ & sig. \\
\cline { 2 - 6 } & $\mathrm{B}$ & Std. Error & Beta & & \\
\hline 1 (constant) & -23.770 & 17.124 & & -1.388 & 0.170 \\
\hline X1 & 0.409 & 0.134 & 0.347 & 3.049 & 0.003 \\
\hline X2 & 0.469 & 0.220 & 0.240 & 2.128 & 0.037 \\
\hline X3 & 0.806 & 0.401 & 0.222 & 2.008 & 0.049 \\
\hline
\end{tabular}


The table above shows the results of multiple linear regression analysis which can be written as follows.

$$
Y=-23,770+0,409(X 1)+0,469(X 2)+0,806(X 3)+e
$$

The linear regression equation can be explained as follows. The constant value of $-23,770$ indicates that if the independent variables of leadership, applicable regulations and human resource competence are absent or zero, then the level of budget achievement is equal to the constant of $-23,770$. The leadership coefficient of 0.409 indicates that an increase of one unit in leadership will result in an increase of 0.409 unit in the budget achievement level with the assumption that other variables are constant. The applicable regulatory coefficient of 0.469 indicates that an increase of one unit in applicable regulation will result in an increase of 0.469 unit in the budget achievement level with the assumption that other variables are constant.

The regression coefficient of determination $\left(\mathrm{R}_{2}\right)$, obtained Adjusted $\mathrm{R}$ Square value $16.8 \%$. It indicates that the contribution of independent variables of leadership, applicable regulations, and human resource competence on the dependent variable (the level of budget achievement) is $16.8 \%$, while the other $83.2 \%$ is determined by other variables. The results of model analysis for leadership, applicable regulations, human resource competence and budget achievement level are presented in Table 4.

Table 4 Model Analysis

\begin{tabular}{cccccc}
\hline Model & $\begin{array}{c}\text { Sum of } \\
\text { Squares }\end{array}$ & df & $\begin{array}{c}\text { Mean } \\
\text { Square }\end{array}$ & F & Sig. \\
\hline 1 Regression & 1282.820 & 3 & 427.607 & 5.641 & $0.002^{\mathrm{b}}$ \\
\hline Residual & 5002.666 & 66 & 75.798 & & \\
\hline Total & 6285.486 & 69 & & & \\
\hline
\end{tabular}

Based on results in Table 3, it can be seen that the budget achievement level is simultaneously influenced by variables of leadership, applicable regulations and human resource competence. It can be seen from $F$ arithmetic of 5,641 that is higher than $F$ table of 2,74, with significant value of 0,002 that is less than 0,05 . So, it can be concluded that the model in this study is feasible to be used.

Based on the results of data analysis, it is known that leadership $\left(X_{1}\right)$ has a significant influence on capital expenditure achievement level. Based on multiple regression analysis results, it is known that the influence of leadership on the level of budget achievement has a t value of 3.049 that is higher than $\mathrm{t}$ table 1.99656, the significant value is 0.003 that is less than 0.05 . This shows that leadership has a significant influence on capital expenditure achievement. As such, it can be concluded that the first hypothesis is supported.

The significant influence of leadership has on the capital expenditure level indicates that the better the leadership is, the better the achievement level of the budget. This is likely to happen if all members of the organization are able to receive good leadership, so that they will carry out what their leader directs so that a predetermined budget can be achieved in accordance with what has been determined. Conversely, the worse the leadership will be the worse the level of achievement of the budget. The results of this study are in line with Fitri et al. (2013) which states that leadership has a significant influence on budget achievement level.

The results in Table 3 also show that the applicable regulations $\left(\mathrm{X}_{2}\right)$ have a significant influence on the capital expenditure achievement level. The results of multiple regression analysis show that the effect of applicable regulations on capital expenditure achievement level has a value of $t$ arithmetic 2.128 that is less than $t$ table of 1.99 and a significant value of 0.037 that is less than 0.05 . This shows that the applicable regulations have a significant influence on the capital expenditure achievement level. So, it can be concluded that the second hypothesis is supported. 
The significant influence of prevailing regulations on the capital expenditure achievement level shows that in order to increase the achievement of capital expenditure realization, every Regional Device Organization (OPD) must comply with the prevailing regulations related to the preparation and execution of the budget. By taking into account the applicable regulation in their process, the OPD's budget achievement can be achieved in accordance with the predetermined target. The results of this study are in line with research conducted by Juliani and Sholihin (2014) which state that the knowledge of the applicable regulations have a positive effect on the budget absorption related to the procurement of goods and services. Adequate knowledge on regulations influence budget absorption related to procurement of goods and services because all activities carried out must comply with applicable regulations. Activities undertaken without following the applicable rules will become a problem for the OPD. Employees who are involved in the procurement process must have a procurement certificate of goods and services as they are in accordance with applicable regulations.

Finally, results in Table 3 also show human resources competence $\left(X_{3}\right)$ has a significant influence on the budget achievement level. The results of multiple regression analysis show that the influence of human resource competence on budget achievement level has a t arithmetic value of 2,008 that is higher than the $t$ table of $-1,99656$ and a significant value of 0.049 that is less than 0.05 . This shows that the human resource competence has a significant influence on the capital expenditure achievement level. So, it can be concluded that the third hypothesis is supported.

It shows that in order to increase the capital expenditure achievement level, staff at OPD must be competent such as mastering various regulations, laws, working procedures, and systems as well as responsive to the timeliness of budget implementation. The results are consistent with Nalarreason, et al. (2014) who reported that human resource competence has a positive and significant influence on budget implementation. because in realizing the demands of the community will dissatisfaction with the implementation of the budget, competent. Competence is not only in terms of intellectual, but there are several aspects contained in term of competence. This encompasses knowledge, skills, self-concept and values, personal characteristics, and motives. The existence of human resource competence will be able to support the achievement of budget implementation.

\section{Conclusions}

This study aims to empirically examine the influence of leadership, applicable regulations and human resources competence on capital expenditure achievement of West Sumatera Local Government. A survey questionnaire was conducted involving 48 Organization of Regional Devices (Organisasi Perangkat Daerah-OPD) in West Sumatera. The data were analyzed using multiple regression technique.

The results of the study show support for all three hypotheses formulated in the study. First, leadership has a significant influence on achievement level of OPD budget at West Sumatera local government. Second, applicable regulations have a significant influence on achievement level of OPD budget in the environment at West Sumatera local government. Finally, human resources competence has a significant influence on the achievement level of OPD budget at West Sumatera local government.

\section{Acknowledgments}

The main author would like to express sincere gratitude to her family, supervisors and the reviewers for the motivation, guidance and constructive feedbacks for carrying out and completing the study. Further, we would also like to express our deepest gratitude to The Finance and Asset Management Agencies in West Sumatera for participating in the study.

\section{References}

Bastian, I. (2010). Sistem Perencanaan dan Penganggaran Pemerintah Daerah di Indonesia. Ketiga. Jakarta: Erlangga.

Fitri, S. M., Ludigdo, U., \& Djamhuri, A. (2013). Pengaruh gaya kepemimpinan, komitmen, organisasi, 
kualitas sumber daya, reward, dan punishment terhadap anggaran berbasis kinerja (Studi empirik pada pemerintah Kabupaten Lombok Barat). Jurnal Dinamika Akuntansi, 5(2), 157-171. Retrieved from http://Journal.Unnes.Ac.Id/Nju/Index.Php/Jda

Gouzali, S. (2005). Manajemen Sumber Daya Manusia. Jakarta: Djambatan.

Juliani, D., \& Sholihin, M. (2014). Pengaruh faktor-faktor kontekstual terhadap persepsian penyerapan anggaran terkait pengadaan barang/jasa. Jurnal Akuntansi dan Keuangan Indonesia, 11(2), 177-199. Retrieved from https://Doi.Org/10.21002/Jaki.2014.10

Kurniawan. (2009). Pengaruh penganggaran berbasis kinerja terhadap akuntabilitas kinerja instansi pemerintah daerah di Wilayah IV Priangan. Universitas Persada Indonesia, Jakarta.

Mardiasmo. (2009). Akuntansi Sektor Publik. Yogyakarta: Penerbit Andi.

Nalarreason, K. M., Atmadja, A. T., \& I. M. P. A. (2014). Pengaruh good governance dan kompetensi sumber daya manusia terhadap implementasi anggaran berbasis kinerja pada dinas pendapatan daerah kabupaten. E-Journal S1 Ak Universitas Pendidikan Ganesha, 2(1).

Ruky, A. S. (2014). Menjadi Eksekutif Manajemen SDM Profesional. Yogyakarta: Penerbit Andi. 